\title{
Roman wealth and wealth inequality in comparative perspective
}

\section{(C) Walter Scheidel (Stanford University)}

Working Paper, Stanford University, Version 1, September 2019

\begin{abstract}
Reflecting current concerns about economic inequality, scholars who study the pre-modern past are increasingly addressing this issue. The obstacles to measuring the distribution of income or wealth in the ancient Roman world are formidable. Only a few highly localized datasets are available. Any appraisal of conditions in the Roman empire as a whole therefore requires parametric modeling. Building on earlier work by Scheidel and Friesen (2009), this paper explores new ways of establishing plausible parameters for a probabilistic reconstruction of the total size of Roman wealth and the share held by the top tier of society.
\end{abstract}




\section{A defining challenge}

In 2013, Barack Obama called rising inequality "the defining challenge of our time." Since the Financial Crises and the Great Recession of 2007-9, the gap between the haves and have-nots has attracted unprecedented attention in politics, the media and academia. ${ }^{1}$ Students of the more distant past have also begun to embrace this trend. Economists are once again looking back in time, inspired in no small measure by the broad impact of Thomas Piketty's work. ${ }^{2}$ Historians are laboring hard to unearth and publish relevant data. Thanks to their efforts, we are now able to glimpse the contours of changes in the concentration of income and wealth over the very long run, at least in some parts of the world. ${ }^{3}$ Archaeologists have been joining the fray, gathering and analyzing plausible proxies of inequality such as house sizes. ${ }^{4}$

Analysis of the material record, which is inevitably local and highly specific in nature, needs to be complemented by macro-level hypotheses that help frame and contextualize fine-grained empirical studies that seek to measure inequality from the ground up. In this paper, I aim to provide a better sense of both the overall scale and the distribution of the material resources of the mature Roman empire (notionally in the mid-second century CE). I do so not merely because these features are worth assessing (even if this involves what might seem an unhealthy dose of conjecture) but also because they have wide-reaching ramifications for our understanding of other aspects of Roman history, from money use to taxation and economic development. In all this, the defining challenge for the ancient historian is a methodological one: how are we to go about studying ancient inequality? ${ }^{5}$

\section{Bottom-up empirics as a dead end}

Asset inequality cannot be studied without numbers. However, quantitative information for the distribution of wealth in the Roman world is scarce. The best documentary evidence has been preserved in administrative records on papyrus from Egypt. The largest dataset comprehensively reports the size of landholdings in one district (nome) of Egypt around 350 CE. It lists only land held by certain urban residents, those who lived in one part of the district's capital Hermopolis and those domiciled in the adjacent district capital of Antinoopolis. The Gini coefficients are fairly high: different versions of these registers yield values of $.715(n=301)$ and $.758(n=441)$. This is not surprising given that only the urban elite would have controlled large estates while many others - for whom access to land was not their principal source of income -owned little. Many if not most inhabitants of the district capitals must have been landless and were

This paper grew out of my contribution to the workshop "Capital in classical antiquity" held in Berlin in April 2018 (see https://www.academia.edu/36775238/Tagungsbericht_Capital_in_Classical_Antiquity_2018_). I would like to thank the organizers, Neville Morley and Christian Wendt, for their invitation.

${ }^{1}$ Obama: https://obamawhitehouse.archives.gov/the-press-office/2013/12/04/remarks-president-economic-mobility. Attention: e.g., https://www.thenation.com/article/the-inequality-industry/.

${ }^{2}$ Most famously Piketty 2014, alongside Milanovic 2011; 2016: 46-117; Milanovic, Lindert and Williamson 2011.

3 Alfani and Di Tullio 2019: 9-13 list recent scholarship on premodern inequality. See http://www.dondena. unibocconi.it/EINITE for their project to gather historical European data. Scheidel 2017 attempts to track the full sweep of the history of economic inequality.

${ }^{4}$ See Flannery and Marcus 2012 for a deep survey. Housing and inequality: Kohler et al. 2017; Kohler and Smith 2018; and specifically for ancient Mediterranean material, see Stephan 2013; Kron 2014; Flohr 2016. Fochesato, Bogaard and Bowles 2019 discuss the complexities of cross-cultural comparisons of premodern evidence for inequality.

${ }^{5}$ This paper serves as a sequel to Scheidel and Friesen 2009. For Roman inequality, see now Scheidel 2017: 71-80 (with the augmented version at https://www.academia.edu/27451138/Empires_of_inequality_ancient_China_and_ Rome), 186-7, 206-7, 319-330. Ober 2017 reconstructs inequality in classical Athens. 
therefore omitted: had they been included, inequality would have been even more pronounced. Conversely, inclusion of rural owners might arguably have lowered the overall Gini coefficients. ${ }^{6}$

This latter conjecture is informed by the fact that village communities tended to be less unequal. In one village in the Fayyum, Karanis, in 308/9 CE, the Gini coefficient for private land reached .478 for 110 local villagers (and .431 for all their land including leaseholds) but .626 (.638) for a small group of nonresidents $(n=18)$. The holdings of 49 urban landlords in the village of Aphrodito in the Antaiopolite nome $c .525 / 6 \mathrm{CE}$ show a similar pattern, for a Gini of .623. By contrast, the relatively lower levels of inequality found in Karanis can also be observed in the nearby village of Philadelphia in $216 \mathrm{CE}$ where the holdings of 183 villagers produce a Gini of .518 for private land. Earlier data from the village of Kerkeosiris in $116 / 15$ BCE, prior to the Roman takeover, that include military allotments and leaseholds of crown land add up to a Gini of .374 for 63 holdings. ${ }^{7}$

All of these snapshots are inherently plausible, reflecting as they do severe disparities in landownership among urban residents, less intense inequality among private landowners in villages, and a more balanced distribution of all land in rural communities. At the same time, none of these texts supports a reconstruction of the distribution of all land even for a single district of a single province, let alone a breakdown of all material assets across the empire. A handful of land registers recorded on inscriptions from other parts of the Roman world are even less helpful: they suffer from massive problems such as small sample size, incompleteness and the exclusions of holdings below certain thresholds. ${ }^{8}$

Turning to archaeology, Pompeii is the only one of the empire's 2,000-odd cities that is sufficiently well preserved and studied to allow us to calculate Gini coefficients for household units based on surface area and room number (.621 and .536, respectively). Even as these data give us a better sense of the contours of local socio-economic stratification, they are impossible to scale up to a region or the entire empire - and are of course of rather limited relevance to the question of the distribution of overall wealth even at the local level. ${ }^{9}$

\section{Parametric modeling as the way forward}

These obstacles might well make it seem impossible to come up with meaningful estimates of the size and distribution of all material assets in the Roman empire - an entity that spanned several million square kilometers and about a quarter of the world's population at the time -, and downright foolish to try. Perhaps paradoxically, it is not: although we cannot hope to build such estimates from the bottom up, in the way this is done for contemporary societies, a top-down approach holds greater promise.

In 2009, when Steven Friesen and I sought to establish estimates for aggregate income and income inequality in the Roman empire of the second century CE, we relied in part on calculations of upper-class wealth. The latter were rooted in fairly conservative assumptions about the size and average fortunes of specific elite groups which were formally defined by minimum wealth thresholds - the senatorial, equestrian and decurional orders -, augmented by looser estimates about the affairs of similarly well-off families outside these circles. This exercise yielded rough estimates attributing some 50 to 80 billion sesterces to the richest 1.5 percent of all households. ${ }^{10}$

\footnotetext{
${ }^{6}$ See Bowman 1985 for a detailed discussion, esp. 158-9 for the Ginis; and Bagnall 1992: 137-9 for a model of conditions in the nome as a whole.

${ }^{7}$ Bagnall 1992: 132-6, esp. 135 (Karanis), 136-7 (Aphrodito), 131 (Philadelphia); Bowman 1985: 151 (Kerkeosiris).

8 Duncan-Jones 1990: 129-42 (updated from 1976: 15-24) reviews the record (five land registers including Hermopolis, i.e. four on inscriptions - three from Italy and one from Asia Minor -; plus one list of water rights from Numidia).

${ }^{9}$ Flohr 2016: 75 calculates the Pompeian Ginis. His attempt (ibid.) to relate his results to Friesen and Scheidel's 2009 estimates concerning the distribution of income across the entirety of the Roman empire mixes up the proverbial apples and oranges.

${ }^{10}$ See Scheidel and Friesen 2009: 75-82 for the underlying evidence, calculations and considerations of constraints on the width of the estimated range.
} 
This turned out to be an unconventional way of defining elite wealth: a focus on the top 1 percent of society, a category that is widely used in contemporary inequality studies (and has since become popularized - and maligned - as "the one percent") would have been more appropriate. In the Roman empire, this group would have encompassed the three orders alongside the uppermost slice of noncategorized elite households. Based on our existing estimates, its minimum wealth could not have been much less than 40 billion sesterces, with 45 to 70 billion representing a more plausible range. Given that actual assets would have exceeded formal thresholds and the existence of very large fortunes was bound to raise the overall mean, a value closer to the higher rather than the lower end of this range is prima facie more realistic. ${ }^{11}$

In theory, it might be possible to raise this estimate even further: after all, we have no way of telling by how much actual fortunes exceeded minimal thresholds. In practice, associated income shares serve as a significant constraint. If we were to define elite income very - and no doubt overly - schematically as equivalent to an average annual return of 6 percent on assets (more on this below), my estimate for the total wealth of the richest 1 percent would imply a corresponding annual income of the order of 3 to 4 billion sesterces. Relative to an annual GDP of the order of a little less than 20 billion, this translates to a top 1 percent income share of roughly one-fifth of all income, a proportion that is large but not unreasonably so by historical standards. This, in turns, speaks against much higher estimates of total elite wealth and thus income. $^{12}$

Combining this estimate with conservative assumptions about stratification within the non-elite population, Friesen and I calculated an overall Gini coefficient of income for the Roman empire of about $.42-.44$, a result that closely matches the mean of about .45 guesstimated for a sample of 28 premodern societies. In the Roman case, this degree of income concentration implies an extraction rate - which measures the share of all income above bare subsistence that was captured by the top earners - of approximately 80 percent, a finding that once again meshes well with a premodern average of around 77 percent in the same sample. ${ }^{13}$

We thus end up with estimates that appear to be adequately robust, constrained as they are by overall GDP and the extraction rate. Neither one of these boundaries is particularly elastic. GDP could not have been much lower without creating a society characterized by universal poverty that is not reflected in the archaeological record. Nor could it have been much higher without approaching the levels attained by the most advanced early modern economies. The extraction rate had to be significantly lower than 100 percent, thereby imposing another limit on elite incomes. ${ }^{14}$

But two serious problems remain. First, it is not quite clear how we are to relate estimates of elite incomes and income shares to elite wealth. The handy shortcut of connecting them by equating elite income with a mean annual return on all assets of 6 percent makes some sense for net returns on invested capital but neglects both income derived from other sources and the presence of non-productive assets. It is true that the former would have increased income relative to wealth while the latter would have reduced it, thereby to some extent offsetting one another. Even so, the margin of error is considerable.

Second, and most importantly, even if it were feasible to extrapolate elite income from elite wealth and vice versa, we would still be ignorant of the share of elite wealth in all wealth. Both historical and contemporary data on inequality leave no doubt that the share of the richest 1 percent of Roman households in all wealth would have been significantly larger than the share of the highest-earning 1 percent of

\footnotetext{
${ }^{11}$ Extrapolated from Scheidel and Friesen 2009: 76 table 6.

${ }^{12}$ See Scheidel and Friesen 2009: 63-74, esp. 74 n.45 for a GDP estimate of 18 billion for computational purposes, the center point of a wider plausible range. For the notion of a 6 percent rate of return, see ibid. 75 n.55. Rich information on more recent top income shares is accessible via the "World Inequality Database" (https://wid.world/).

${ }^{13}$ Scheidel and Friesen 2009: 86 (Gini), 87 n.88 (extraction rate). For the concept of the extraction rate (or ratio), see Milanovic, Lindert and Williamson 2011: 256-9. For further discussion, see Milanovic 2013 and Scheidel 2017: 44556. 28 historical comparanda: Milanovic, Lindert and Williamson 2011: 263 table 2.

${ }^{14}$ For these constraints on GDP and elite income, see Scheidel and Friesen 2009: 74, 88, as well as 91 on the higher GDP estimate by Lo Cascio and Malanima 2009.
} 
households in total income. The labor income of the asset-poor masses consistently raises their income share beyond their wealth share: it is possible to live without net assets but not without any income. As result, wealth has invariably been more concentrated at the top than income, and the same was bound to be the case in Roman society. But by how much?

There are two ways of getting a better sense of Roman elite wealth shares, and thereby of the volume of total wealth. Both of them depend on historical analogy. The earliest set of country-scale information on wealth shares dates from the late eighteenth and the beginning of the nineteenth century (1770s-1810). At that time, top 1 percent wealth shares in several European countries ranged from about one-third to a little more than half of national wealth: $c .35$ percent in Finland, $c .45$ percent in France and Norway, $c .50$ percent in Sweden, and c.55 percent in Denmark and the United Kingdom. Smaller shares in the United States were an outlier. ${ }^{15}$

In terms of political power asymmetries and social stratification, the Roman empire had more in common with these European countries than with the United States, which speaks for a higher degree of wealth concentration than in the latter. A top wealth share of somewhere around half might thus seem like a defensible working assumption. ${ }^{16}$

This notion can be tested by means of a different analogy, derived from historical ratios of income to wealth. Piketty provides estimates for the ratio of total national wealth relative to annual national income in France, Britain and the United States from the eighteenth century onward. In France in 1700, total national wealth is estimated to have equaled seven times annual national income, a rough equivalent of GDP. Almost two-thirds of that wealth was embodied in agricultural land, with the remainder fairly evenly split between housing stock and other domestic capital. In Britain in 1700, by contrast, the wealth/income ratio was the same ( 7 to 1 ) but, due to greater development, farmland played a somewhat smaller role and domestic capital a larger one. Meanwhile, in the United States, where land was abundant, its share in national wealth was much more modest, and the overall wealth to income ratio of about 5 to 1 was therefore significantly lower as well. Although all these breakdowns must be taken with a healthy dose of caution, the way they change over time as they approach the more recent past confirms their value as useful approximations. ${ }^{17}$

For the purpose of comparison, we can once again eliminate the experience of the American settler society with its cheap land and less entrenched inherited wealth. The Roman wealth/income ratio had to be higher. Of the two European comparanda on offer, France ought to be more suitable (or at least less unsuitable) as an analogy than Britain, one of the first economies to experience modern economic growth. In important respects, France in 1700 was not radically different from the Roman empire. It matters little that the latter's population was at least three times as large. Both were predominantly agrarian and firmly pre-industrial "organic economies" characterized by a high degree of urban primacy (centered on Rome and Paris) and autocratic central institutions coupled with dispersed oligarchic power and privilege.

\footnotetext{
${ }^{15}$ Roine and Waldenström 2015: 539 fig. 7.19, 572 table 7.A2. US shares were less than 20 percent for households and close to 30 percent for individuals. See Lindert and Williamson 2016: 13-42 for exceptionally low economic inequality during and right after the colonial era. It is comforting to see that concentration levels seem insensitive to country size, which helps clear the way for inferences about the considerably larger Roman empire.

${ }^{16}$ Maiuro 2012: 117-45, esp. 125-31, proposes a much lower wealth share of $c .30$ percent for the richest 1 percent (127) whilst considering a top 0.43 percent share of 39.4 percent of all real estate as a theoretical maximum (131). However, it not clear how the putative assets of Roman veterans (125-6) can be used to support his claim that a quarter of households were bound to own as much as or more than ordinary veterans: we can hardly expect a sizeable population that received identical allotments to fit neatly into a Pareto distribution, nor do we know how much of their discharge bonuses veterans on average retained in the form of yield-bearing assets. For the bulk of the military population (active soldiers), moreover, income was completely unrelated to wealth (cf. 127).

${ }^{17}$ Piketty 2014: 116 fig.3.1 (Britain), 117 fig.3.2 (France), 160 fig.4.10 (US). For the shortcomings of late seventeenthcentury attempts to estimate British income and wealth, see Slack 2004. William Petty's estimates for $c .1665$ imply a ratio of 6.25 to 1 and Gregory King's for 1688 suggest a ratio of 7.1 to 1 (Slack 2004: 614). Income may have been higher than King allows for - one adjustment suggests a ratio of 5.8 instead (ibid. 626), but that would only be valid if wealth had not been underestimated as well.
} 
When it comes to key metrics, in so far as they can be (dimly) discerned, the two systems did not differ much. France's putative per capita GDP of about \$1,700 (in 2011\$) was not dramatically higher than that of $\$ 1,250$ Friesen and I estimated for the Roman empire. ${ }^{18}$ Judging by extraction rates, income was similarly unevenly distributed. ${ }^{19}$ The share of the population residing in urban settlements of 5,000+, a vital proxy of economic development, was likewise more or less the same, around 13 percent in France and perhaps between 10 and 12 percent in the Roman empire. ${ }^{20}$ Mean life expectancy at birth stood at about 25 years in France and in Roman Egypt, and was probably not very different elsewhere in the empire. ${ }^{21}$ One study has identified similarities in terms of the sophistication of Roman and French financial institutions. ${ }^{22}$ In both societies, most people were peasants, of very modest means and illiterate, and wealthy elites wielded local power and enjoyed fiscal privileges.

If we apply the wealth/income ratio for France in 1700 to the Roman empire in the second century $\mathrm{CE}$, the latter's total wealth would have approximated seven times GDP, or around 126 billion sesterces. Both the underlying GDP estimate and the multiplier are so rough as to discourage tinkering. Even so, a single adjustment may be worth undertaking in order to account for the Roman practice of slaveownership. Property claims in human beings likely boosted overall Roman wealth. ${ }^{23}$ In the United States around 1800, the value of slaves equaled more than a year's worth of national income, and no less than about $2 \frac{1}{2}$ times annual income in the southern states, where slaves infamously made up close to half of total wealth in 1860. Because of this, the wealth/income ratio in the Antebellum South was twice that of the North, 6 times instead of 3. This speaks in favor of including Roman slavery in the equation to see how much it affects the total. ${ }^{24}$

This inevitably requires further conjecture. If we put the imperial slave population at around onetenth of the total - in an earlier study, triangulating from estimates for Italy and Egypt, I guesstimated 5 to 8 million slaves out of a total of about 65 million, or 7 to 13 percent -, we arrive at something like 6 or 7 million slaves. An adult slave without special skills would have been valued at about 4 tons of wheat equivalent, or 1,500 sesterces for the purposes of our calculations. Sub-adult slaves might on average have been priced at perhaps half as much. Thus, 6 or 7 million slaves might have been worth something like 7 to 9 billion sesterces, equivalent to up to half of GDP. ${ }^{25}$ This approach neglects a long "tail" of a minority of much more highly valued slaves who would have raised actual averages. At, say, a mean of 1,500 to 2,000 sesterces per slave, the slave population would have represented an additional 9 to 13 billion sesterces in wealth. This does not exceed 10 percent of the original wealth estimate, and may thus well fall within the margin of error. If we do add slaves to the mix, the schematic asset tally rises to 135 or 140 billion sesterces.

Borrowing the notion of a top 1 percent wealth share of 45 to 55 percent from late eighteenthcentury Denmark, France, Norway, Sweden and the United Kingdom, we may now conjecture Roman elite wealth of somewhere between 60 and 75 billion sesterces. This compares well with our 2009 guesstimate of a total near the higher end of a range from 45 to 70 billion. This convergence matters because the previous

\footnotetext{
${ }^{18}$ French GDP: Maddison Project Database 2018, https://www.rug.nl/ggdc/historicaldevelopment/maddison/releases/ maddison-project-database-2018 (mean for France 1695-1705); Roman GDP: derived from Scheidel and Friesen 2009: 91 (converted from 1990\$).

${ }^{19}$ Milanovic, Lindert and Williamson 2011: 263 table 2.

${ }^{20}$ Estimated from de Vries 1984: 39, 65 (France); Wilson 2011: 191 table 7.16 (Roman empire), for a mid-value of 10.6 percent, or $>10$ percent to $>12$ percent depending on imperial population size.

${ }^{21}$ Roman life expectancy: Frier 2000: 789; Scheidel 2007: 39; France: Bagnall and Frier 1994: 88 n.37 for references.

${ }^{22}$ Temin 2013: 166-8, 189 (according to whom Rome did better than eighteenth-century France).

${ }^{23}$ One might ask if the presence of slaves does not also inflate income, assuming we counted them, in economic terms, as "finished products," but on conventional definitions of national income that would not be so: cf. Piketty 2014: 161 fig.4.11 for a perspective that appears to side with the latter position. Either way, the effects on total asset value is relatively small.

${ }^{24}$ Piketty 2014: 160-1 figs.4.10-11 (ratios); Wright 2006: 60 table 2.4 (1860).

${ }^{25}$ Based on calculations in Scheidel 2005 (prices) and 2011: 292 (numbers). Goldsmith 1987: 57 arrives at a much higher total via a crude multiplication of 9 million slaves by 2,000 sesterces.
} 
estimate was extrapolated from ancient evidence for wealth requirements whereas the one I have developed here is exclusively based on analogy with other pre-industrial societies. They are completely independent.

For this reason, their overlap ought to instill a measure of confidence. Even though it is not strictly speaking impossible that we somehow massively misunderstand the ancient record and/or that historical analogies are simply not applicable to the Roman case, none of this seems very likely. Our text-based estimate is (however loosely) constrained by the parameters of GDP and extraction rate. There is no obvious reason why the Roman empire should have been much more unequal than extremely unequal European societies 200 years ago: it was not a petro-state, commoners had property rights, and the archaeological record leaves no doubt about the presence of plenty of middling households between the elite and the more or less poor. At the same time, the Roman world was hardly as egalitarian as the early United States. ${ }^{26}$

We can now work with estimates that seem reasonably robust: a top 1 percent wealth share of around one-half and a top 1 income share of around one-fifth. Moreover, the analogy with France in 1700 suggests a crude disaggregation of different types of wealth: if total Roman assets were worth around 140 billion sesterces, agricultural land would have been worth $c .90$ billion, housing $c .20$ billion, other domestic capital another $c .20$ billion, and slaves $c .10$ billion. ${ }^{27}$ Whilst rough and ready, these figures are nevertheless unlikely to be wide of the mark: agrarian assets must have occupied a dominant position, which leaves little room for dramatic variation in other categories. ${ }^{28}$

\section{Why does it matter?}

This exercise not only sheds some light on the overall contours of the Roman economy but also has more far-reaching ramifications. By gaining a sense of the aggregate value of assets across the empire, we are able to test propositions regarding other issues. I explore three of these: the money stock, effective tax rates, and the savings rate.

First of all, our wealth estimate can be employed as a check on modern claims concerning levels of monetization. Richard Duncan-Jones's estimate that by the mid-second century CE, the total value of all coins in the Roman empire had reached some 20 billion sesterces implies that coined metal accounted for about one-seventh of total wealth. This would be an extraordinarily large share, equivalent to the French share of all domestic capital other than land or housing in $1700 .^{29}$

\footnotetext{
${ }^{26}$ In terms of (income) inequality, the Roman empire may have had more in common with the United States today: Scheidel 2017: 455 n.11.

${ }^{27}$ Without wishing to place too much weight on the thoroughly inadequate empirical record, I should note that the estimate of $c .20$ billion sesterces for housing seems consistent with what little data we have. Assuming an average of 6-7 persons per house (see Hobson 1985 for a mean of 7.3 for Roman Egypt; households were smaller: Bagnall and Frier 1994: 68), the population of the empire would have required up to 10 million houses for residential purposes. If private housing accounted for something like two-thirds or three-quarters of the total value of the housing stock, the average house would have cost around 1,000 sesterces. House prices from Roman Egypt vary widely but point to relatively low costs overall: 26 house prices from the 60s to the 170s CE average close to 700 drachmas/sesterces; only 6 of them exceeded 1,000. For these data, see Drexhage 1991: 71-91, who prudently refrains from this kind of computation. My sample omits dilapidated houses and uncertainly dated reports but extrapolates from fractional values.

${ }^{28}$ The only previous breakdown that I am aware of, Goldsmith 1987: 57-8, assigns greater value to land (110 billion or 5.5 times GDP) and slaves (18 billion, see above, n.25) and less to other categories, for a total of more than 160 billion or 8.2 times national product, although his own tabulation confusingly implies a 7.2 ratio instead (58). (And this is not the only source of confusion: see below, n.33). Land value is derived from a string of conjectures (56) that puts farming income at 60 percent of GDP, rent income at half that, and the value of land at 17 times annual yields of 6 percent (which however implies 5.1 rather than 5.5 times GDP, in keeping with the French ratio of about 5 times GDP for 1700).

${ }^{29}$ Duncan-Jones 1994: 168-70.
} 
Converted into silver, Duncan-Jones's estimate translates to $c .225$ grams of silver per person, significantly more than the $c .140$ grams per person that have been estimated for France around 1680. This is more problematic than it might seem because the purchasing power of silver in early modern Europe was considerably lower than it had been in the Roman empire, in part because imports of New World bullion had brought about a "price revolution." ${ }^{30}$ Purchasing power expressed in wheat equivalent puts the comparison on a more solid footing. The Roman coined money stock corresponds to $c .1,000$ liters of wheat per person whereas the French coined money stock around 1680 could only have bought $c .175$ liters per person at Paris prices. Even allowing for substantially higher prices in Paris than in France as a whole, the implied difference is very large. Would the Roman empire really have been so much more coin-rich than early modern France? ${ }^{31}$

Or England, for that matter? According to Gregory King's famous breakdown, coinage accounted for less than 4 percent of all wealth in England near the end of the seventeenth century, an estimate that does not seem to be wide of the mark. ${ }^{32}$ Why would the corresponding share in the Roman empire have been four times as large? Recourse to Occam's Razor suggests that Duncan-Jones's estimate is likely to be inflated. A coined money stock valued at a full year's worth of GDP would render the Roman case highly unusual indeed, requiring us to raise the total wealth estimate by about one-tenth just to accommodate lavish bullion stocks - not impossible but hardly economical. A more restrained appraisal would have much to commend it. ${ }^{33}$

My second point concerns Roman fiscality. On previous occasions, I have argued that there must have been a huge gap between nominal tax rates and the amount of revenue that actually reached the central authorities: receipts based on nominal rates would have been far too high to be accommodated within what we know about imperial spending patterns. ${ }^{34}$ My estimate of total Roman wealth is consistent with this view. A - necessarily exceedingly crude - calculation shows why. Assume that in order to support some 60 to 75 million - say, for the sake of simplicity, 70 million - people in the empire in the second century $\mathrm{CE}$, at least $200 \mathrm{~kg}$ of grain had to be grown per person per year (for consumption plus spoilage); that grain yields net of seed averaged c.550 kg per hectare; and that only half of all arable land was under grain in any given year. In this scenario, some 55 million hectares of land would have been arable, or roughly one-

\footnotetext{
${ }^{30}$ The Roman estimate is derived from coins' mean bullion content reported in Duncan-Jones 1994: 223-32. For the French estimate, see Glassman and Redish 1985 . Higher purchasing power in early modern France (and Europe) is amply documented by the consumption basket estimates in Allen 2009 (for which see below) and the price data gathered at http://www.iisg.nl/hpw/data.php (s.v. Europe).

31 The wheat equivalent estimates are based on Scheidel and Friesen 2009: 68 (Roman empire); http://www.iisg.nl/hpw/poynder-france.php (Paris).

${ }^{32}$ Gregory King for 1688: Slack 2004: 621, who deems this estimate probably too low. (William Petty's estimate of 2.4 percent for $c .1665$ is inadequate: Slack 614, 621). However, Palma 2016: 12-13 implies a share of 3.2 percent for 1688. In the United States today, MB (total currency) equals 4 percent of total assets, whereas M3 (which includes bank reserves and deposits) amounts to one-seventh.

${ }^{33}$ If the Roman empire had been twice as coin-rich in per capita terms as late seventeenth-century England, we would need to raise the Roman wealth total by perhaps 5 billion, well within even conservative margins of error for the overall estimate. Goldsmith 1987: 41 speculates that coin metal may have been worth 7 billion sesterces in 14 CE, which would imply an even higher later total, but simultaneously reckons with a much smaller share -0.2 times GDP, or 4 billion, in his own breakdown (58), which does not make sense. The importance of credit money in the Roman economy (see most recently Harris 2019) also counsels against exaggerating the physical money stock. Lo Cascio 2008: 162-4 finds Duncan-Jones's estimate high but not impossible. However, of the three factors he invokes in its defense - the possibility of higher monetization levels, higher GDP, and lower coin circulation velocity - the first two cannot take us very far because they are ultimately constrained by comparative evidence. This puts most weight on low velocity, inviting us to envision rich Romans sitting on piles of gold like fairy-tale dragons.

${ }^{34}$ Scheidel 2015a: $156-63$ and 2015b: 242-7, based on the likely scale of expenses (dominated by military demand) and revenues (among which income from mines, tolls and imperial domains loomed large, accounting for perhaps up to half of total revenue), and constrained by what (little) we know about government saving and responses to shortfalls, such as coin debasement. Hopkins 2002: 199-201 foreshadowed but did not develop this line of reasoning.
} 
seventh of the surface area of the empire excluding major desert zones. In reality, spoilage would have been higher and fallowing less important, without greatly affecting overall orders of magnitude. ${ }^{35}$

This farmland must have been worth less than the total of $c .90$ billion sesterces conjectured for all agricultural land (which included land devoted to arboriculture and so forth), even if we do not know by how much. If we were to speculate, for the sake of argument, that arable accounted for half of the total value of all agricultural land (alongside a much larger physical share of cultivated land), the average price of arable land would have been about 800 sesterces per hectare (and much more for more intensively cultivated land). This result is consistent with what little we can say about Roman land prices and therefore unlikely to be wildly incorrect. Less fallow, more spoilage or a different split between arable and other farmland would all result in different averages, but not by very much. Per capita consumption cannot have been much lower (without inducing mass starvation) or much higher (without turning the Roman empire into a world of plenty), grain yields cannot have been dramatically different, and for all we can tell, grainland prices typically amounted to 100s of sesterces per quarter-hectare rather than to scores or thousands. My estimate may be very rough but is not infinitely elastic, and is adequate for the very limited purposes of my argument. ${ }^{36}$

Notionally priced at 0.5 sesterces per kilogram, total annual grain output (of $200 \mathrm{~kg}$ per person for 70 million consumers) would have been worth 7 billion sesterces, perhaps a little more than one-third of GDP. This share is perfectly plausible: separate estimates put total agrarian output at around 80 percent of GDP in England and Wales near the end of the thirteenth century, at close to 60 percent in central and northern Italy in the early fifteenth century, at about 70 percent in China as recently as the second half of the nineteenth century, and at up to two-thirds in India around $1900{ }^{37}$ If, in the Roman case, some 60 to 80 percent of arable output was subject to taxation - excluding Italian soil and other exempt locales -, a tithe

\footnotetext{
${ }^{35}$ Population and area: Scheidel 2007: 48 (60-70/75 million); Scheidel and Friesen 2009: 66 use 70 million for GDP calculations, which I why I do the same here. Yields: Spurr 1986: 82-88 (which makes yields of $c .5$ to 1 seem reasonable), see also 56-7 for sowing amounts (maybe 5 modii per iugerum for wheat). Consumption: $150 \mathrm{~kg}$ would have been the annual minimum net of spoilage (Garnsey 1998: 229-30), but de facto 170-180 kg is more likely. See Scheidel 2001: 239-41 for references: I assume that three-quarters of $240 \mathrm{~kg}$ of wheat (caloric) equivalent were consumed in the form of grains. Adding modest spoilage thus yields a minimum of $c .200 \mathrm{~kg}$. Allowing for aboveminimum consumption levels and greater spoilage, the actual mean was presumably higher than that.

${ }^{36}$ Columella's (RR 3.3.8) reference to a price of 1,000 sesterces per ingerum (i.e., 4,000/hectare) for uncultivated (!) land is considered too high even for actual arable: see Duncan-Jones 1982: 48-52, and also 347-8 for North Africa. De Neeve 1985 discusses the various determinants of land value. (I hope to show that he was not quite right to maintain that we are unable to establish an average price for agricultural land [98]: averages always exist, even if they are unknown or do not mean much in most contexts.) In the second century CE, Egyptian (arable) farmland was worth c. 200 drachmas ( sesterces) per aroura (0.276 hectares): Scheidel 2002: 102; cf. also Duncan-Jones 1982: 366. Albeit more productive than most land elsewhere, it was also devalued by heavy taxes. Augustus's spending on veterans of 5,500 sesterces per head would have been enough to purchase 20 iugera (5 hectares) at 275 sesterces per iugerum (or 1,100 per hectare); if funds were needed for investment, land prices had to be lower: cf. Duncan-Jones 1976: 10-11 (who reckons with too modestly sized allotments for imperial veterans: reported sizes from the Republican period range from 10-12 iugera [of presumably very fertile land] for civilians in Campania to 50 for settlers in Aquileia when it was an undesirable frontier location).

${ }^{37}$ Grain price: Scheidel and Friesen 2009: 68. GDP shares: Campbell 2008: 940 (England); Malanima 2011: 182 (Italy); Ma and de Jong 2019: 93-4 (China); Goldsmith 1984: 282 (India). Goldsmith 1984: 273, 276, 282 values food grains at one-third of Roman GDP and farming output at 60 percent; see also 1987: 56. Goldsmith 1984: 281-2 cites examples of food grains accounting for 50-60 percent of the value of total food consumption in several premodern societies. In addition, "consumption baskets" suggest that grains and legumes accounted for a little less than half of the cost of the idealized food intake of a male worker in eighteenth-century northern Europe and in Strasbourg, and a little more than half in Naples. The corresponding shares are about one-half for a "respectable" consumption basket based on Diocletian's Price Edict, up to one-third for a "respectable" basket in second-century CE Roman Egypt, and two-thirds of a "bare-bones" basket there: see Allen 2009: 332-5 and Scheidel 2010: 427-436. In the aggregate, total spending on agricultural products had to match their total value, which underlines the relevance of consumption patterns for our understanding of output shares.
} 
on grain harvests would have yielded 400 to 500 million sesterces worth of revenue per year. ${ }^{38}$ If we also assume a similar output total for other forms of agriculture - which would bring the Roman agrarian GDP share in line with the aforementioned examples - as well as a similar tax load, taxable land ought to have brought in some 800 million to a billion sesterces in annual revenue - a figure close to the entire imperial budget.

This is a serious problem. There can be little doubt that hundreds of millions of sesterces flowed into the imperial coffers from other sources, such as mines and tolls. Effective tax receipts on agricultural goods must therefore have been less than 10 percent, and closer to the 5-7 percent of GDP the central government could expect to capture. Notwithstanding sizeable margins of uncertainty, there is simply no way that tax rates of 15 to 20 percent that have recently been proposed on the basis of Egyptian evidence and that are also independently reported for other parts of the empire reflected actual state revenues. ${ }^{39}$

This does not mean that the authorities did not wish or try to collect that much - nominal tax rates were presumably as high as the sources claim: it means that only a fraction of the taxes owed to the central government reached it while the remainder was lost to concealment, remissions and fraud by intermediaries. My wealth estimate confirms the impression that the fiscal capabilities of the mature empire were severely limited by information and agency problems, which go a long way in explaining why revenue could not ready be increased in emergencies and the empire eventually failed.

A third insight can be derived from Piketty's "second fundamental law of capitalism," the premise that $\beta=\mathrm{s} / \mathrm{g}$, where $\beta$ is the national capital/income ratio, $\mathrm{s}$ is the savings rate net of capital depreciation, expressed as a percentage of annual national income, and $\mathrm{g}$ is the annual percentage rate of economic growth. For the United States from 1970 to 2010 , for example, s was 7.7/1.8 $=4.3$ percent. $^{40}$

What about the Roman empire? If we put $\beta$ at $7-8$ and $g$ at $0.2-0.25$, s would be a little over $1 \frac{1}{2}$ percent of GDP, or roughly 300 million sesterces per year. ${ }^{41}$ This would translate to something like 4 or 5 sesterces per person per year, a minuscule amount. As a result, capital accumulation had to be very slow. This in turn put a premium on predatory accumulation, such as slaving, which allowed value to be created ex novo, and favored internal predation (such as rent-seeking behavior by elites) over market-based economic activity. Very low per capita savings were typical of an economy in which human capital investment was low as well, a feature that put a brake on intensive growth. Thus, while the savings rate may seem a recondite concept, it helps flesh out our appreciation of Roman economic performance and potential. $^{42}$

This may be as far as we can push it: we will most likely never gain a more solid understanding of Roman wealth stocks and their distribution. ${ }^{43}$ Yet as I hope to have shown, even wide margins of uncertainty

\footnotetext{
${ }^{38}$ Italian land was not taxed: its inhabitants made up perhaps one-ninth (and at most one-seventh) of the empire's population (Scheidel 2007: 48 table 3.1). Its cultivated area could have been as large as $100,000 \mathrm{~km}^{2}$, or close to onefifth of the empire's total arable if three-quarters of Italian farmland had been arable. Given higher prices in the imperial heartland (see von Freyberg 1989 for this premise), Italian arable output could have accounted for more than 20 percent of the value of all arable output in the empire, hence my adjustment of up to 40 percent for Italy and other tax-exempt locales combined. This uncomfortably wide range reflects the scale of the underlying uncertainties.

${ }^{39}$ Receipts: Scheidel and Friesen 2009: 75. Nominal rates: Bowman 2018, who seems oblivious to the difference between nominal and effective rates.

${ }^{40}$ Piketty 2014: 166-70.

${ }^{41}$ I allow for a multiplier of up to 8 in order to account for slaves and the possibility somewhat greater bullion stocks, as discussed above. For a plausible rate of population growth ( 0.15 percent per year net of territorial expansion), see Frier 2000: 813, and cf. Scheidel 2007: 43-44. For economic growth, Saller 2002: 260 (a mere guess of less than 0.1 percent annual per capita growth, but not unreasonable: cf. Goldsmith 1984: 287-8; Scheidel 2007: 44). The annual capital formation rate in India in the late nineteenth century was $c .2$ percent, and annual per capita growth was as low as 0.2 percent: Goldsmith 1984: 284, who also posits a growth rate of 2 percent or less for the Roman empire.

${ }^{42}$ See esp. Bang 2012 (predation) and Saller 2012 (human capital). See also already Goldsmith 1984: 287.

${ }^{43}$ Other implications of my findings are mere curiosities: for instance, each of the richest Romans (endowed with personal fortunes of 300-400 million sesterces) would have owned about one quarter of a percent of the empire's total wealth, compared to the one-tenth or so of a percent of US assets currently owned by each of the richest Americans.
} 
are no reason for despair. Analogy is an essential part of our toolkit: one not designed to make all societies look alike - which they most certainly did not - but to expand as well as rein in our imagination by suggesting options that are rooted in actual historical outcomes and by staking out the limits of the plausible. Sharpened by tentative quantitative reasoning, this perspective helps us develop scenarios that are consistent with the broader experience of premodern societies; that are compatible with the ancient data we happen to have; and that are constructed along different pathways to guard against circularity. My reconstructions of Roman wealth and wealth inequality meet all of these conditions. 


\section{References}

Alfani, Guido and Di Tullio, Matteo. 2019. The lion's share: inequality and the rise of the fiscal state in preindustrial Europe. Cambridge: Cambridge University Press.

Allen, Robert C. 2009. "How prosperous were the Romans? Evidence from Diocletian's Price Edict (AD 301)." In Bowman, Alan and Wilson, Andrew, eds. Quantifying the Roman economy: methods and problems, 327-345. Oxford: Oxford University Press.

Bagnall, Roger S. 1992. "Landholding in late Roman Egypt: the distribution of wealth." Journal of Roman Studies 82: 128-149.

Bagnall, Roger S. and Frier, Bruce W. 1994. The demography of Roman Egypt. Cambridge: Cambridge University Press.

Bang, Peter F. 2012. "Predation." In Scheidel, Walter, ed. The Cambridge companion to the Roman economy, 197-217. Cambridge: Cambridge University Press.

Bowman, Alan K. 1985. "Landholding in the Hermopolite nome in the fourth century AD." Journal of Roman Studies 75: 137-163.

Bowman, Alan. 2018. "The state and the economy: fiscality and taxation." In Wilson, Andrew and Bowman, Alan, eds. Trade, commerce, and the state in the Roman world, 27-52. Oxford: Oxford University Press.

De Neeve, Pieter W. 1985. "The price of agricultural land in Roman Italy and the problem of economic rationalism.' Opus 4: 77-109.

De Vries, Jan. 1984. European urbanization, 1500-1800. London: Methuen.

Drexhage, Hans-Joachim. 1990. Preise, Mieten/Pachten, Kosten und Löhne im römischen Ägypten bis zum Regierungsantritt Diokletians. St Katharinen: Scripta Mercaturae Verlag.

Duncan-Jones, Richard P. 1976. "Some configurations of landholding in the Roman empire." In Finley, Moses I., ed. Studies in Roman property, 6-33. Cambridge: Cambridge University Press.

Duncan-Jones, Richard. 1982. The economy of the Roman empire: quantitative studies. $2^{\text {nd }}$ ed. Cambridge: Cambridge University Press.

Duncan-Jones, Richard. 1990. Structure and scale in the Roman economy. Cambridge: Cambridge University Press.

Duncan-Jones, Richard. 1994. Money and government in the Roman empire. Cambridge: Cambridge University Press.

Flannery, Kent and Marcus, Joyce. 2012. The creation of inequality: how our prehistoric ancestors set the stage for monarchy, slavery, and empire. Cambridge MA: Harvard University Press.

Flohr, Miko. 2016. "Quantifying Pompeii: population, inequality, and the urban economy." In Flohr, Miko and Wilson, Andrew, eds. The economy of Pompeii, 53-84. Oxford: Oxford University Press.

Fochesato, Mattia, Bogaard, Amy, and Bowles, Samuel. 2019. "Comparing ancient inequalities: the challenges of comparability, bias and precision." Antiquity 93: 853-869.

Frier, Bruce W. 2000. "Demography." In Bowman, Alan K., Garnsey, Peter, and Rathbone, Dominic, eds., The Cambridge ancient history, $2^{\text {nd }}$ edition. Volume XI: the high empire, A.D. 70-192, 787-816. Cambridge: Cambridge University Press.

Garnsey, Peter. 1998. Cities, peasants and food in classical antiquity: essays in social and economic history. Edited with addenda by Walter Scheidel. Cambridge: Cambridge University Press.

Glassman, Debra and Redish, Angela. 1985. "Estimates of the money stock in France, 1493-1680." Journal of Economic History 45: 31-46.

Goldsmith, Raymond W. 1984. "An estimate of the size and structure of the national product of the early Roman empire." Review of Income and Wealth 30: 263-288.

Goldsmith, Raymond W. 1987. Premodern financial systems: a historical comparative study. Cambridge: Cambridge University Press.

Harris, William V. 2019. "Credit-money in the Roman economy." Klio 101: 158-189.

Hobson, Deborah W. 1985. "House and household in Roman Egypt." Yale Classical Studies 28: 211-229. 
Hopkins, Keith. 2002. "Rome, taxes, rents and trade.” In Scheidel, Walter and von Reden, Sitta, eds. The ancient economy, 190-230. Edinburgh: Edinburgh University Press.

Kohler, Timothy A. et al. 2017. "Greater post-Neolithic wealth disparities in Eurasia than in North America and Mesoamerica." Nature 551: 619-622.

Kohler, Timothy A. and Smith, Michael E., eds. 2018. Ten thousand years of inequality: the archaeology of wealth differences. Tucson: University of Arizona Press.

Kron, Geoffrey. 2014. "Comparative evidence and the reconstruction of the ancient economy: GrecoRoman housing and the level and distribution of wealth and income." In de Callataÿ, Francois, ed. Quantifying the Greco-Roman economy and beyond, 123-146. Bari: Edipuglia.

Lindert, Peter H. and Williamson, Jeffrey G. 2016. Unequal gains: American growth and inequality since 1700. Princeton: Princeton University Press.

Lo Cascio, Elio. 2008. "The function of gold coinage in the monetary economy of the Roman empire." In Harris, William V., ed. The monetary systems of the Greeks and Romans, 160-173. Oxford: Oxford University Press.

Lo Cascio, Elio and Malanima, Paolo. 2009. "GDP in pre-modern agrarian economies (1-1820 AD): a revision of the estimates." Rivista di Storia Economica 25: 391-419.

Ma, Ye and de Jong, Herman. 2019. "Unfolding the turbulent century: a reconstruction of China's historical national accounts, 1814-1912." Review of Income and Wealth 65: 75-98.

Maiuro, Marco. 2012. Res Caesaris: ricerche sulla proprietà imperial nel Principato. Bari: Edipuglia.

Malanima, Paolo. 2011. "The long decline of a leading economy: GDP in central and northern Italy, 13001913." European Review of Economic History 15: 169-219.

Milanovic, Branko. 2011. The haves and the have-nots: a brief and idiosyncratic history of global inequality. New York: Basic Books.

Milanovic, Branko. 2013. "The inequality possibility frontier: extensions and new applications." World Bank Policy Research Paper No. 6449.

Milanovic, Branko. 2016. Global inequality: a new approach for the age of globalization. Cambridge MA: Harvard University Press.

Milanovic, Branko, Lindert, Peter H., and Williamson, Jeffrey G. 2011. "Pre-industrial inequality." Economic Journal 121: 255-272.

Ober, Josiah. 2017. "Inequality in late-classical democratic Athens: evidence and models." In Bitros, George C. and Kyriazis, Nicholas C., eds. Democracy and an open economy world order, 125-146. Cham: Springer.

Palma, Nuno. 2016. "Reconstruction of annual money supply over the long run: the case of England, 12791870.” European Historical Economic Society Working Papers in Economic History no. 94.

Piketty, Thomas. 2014. Capital in the twenty-first century. Cambridge MA: Harvard University Press. Roine, Jesper and Waldenström, Daniel. 2015. "Long-run trends in the distribution of income and wealth." In Atkinson, Anthony B. and Bourguignon, Francois, eds. Handbook of income distribution. Volume 2A, 469-592. Amsterdam: North-Holland.

Saller, Richard. 2002. "Framing the debate over growth in the Roman economy." In Scheidel, Walter and Von Reden, Sitta, eds. The ancient economy, 251-269. Edinburgh: Edinburgh University Press.

Saller, Richard. 2012. "Human capital and economic growth." In Scheidel, Walter, ed. The Cambridge companion to the Roman economy, 71-86. Cambridge: Cambridge University Press.

Scheidel, Walter. 2001. Death on the Nile: disease and the demography of Roman Egypt. Leiden: Brill. Scheidel, Walter. 2002. "A model of demographic and economic change in Roman Egypt after the Antonine plague." Journal of Roman Archaeology 15: 97-114.

Scheidel, Walter. 2005. 'Real slave prices and the relative cost of slave labor in the Greco-Roman world." Ancient Society 35: 1-17.

Scheidel, Walter. 2007. "Demography." In Scheidel, Walter, Morris, Ian, and Saller, Richard P., eds., The Cambridge economic history of the Greco-Roman world, 38-86. Cambridge: Cambridge University Press. 
Scheidel, Walter. 2011. "The Roman slave supply." In Bradley, Keith and Cartledge, Paul, eds., The Cambridge world history of slavery, 1: The ancient Mediterranean world, 287-310. Cambridge: Cambridge University Press.

Scheidel, Walter. 2015a. "State revenue and expenditure in the Han and Roman empires." In Scheidel, Walter, ed., State power in ancient China and Rome, 150-180. New York: Oxford University Press.

Scheidel, Walter. 2015b. "The early Roman monarchy." In Monson, Andrew and Scheidel, Walter, eds., Fiscal regimes and the political economy of premodern states, 229-257. Cambridge: Cambridge University Press.

Scheidel, Walter. 2017. The great leveler: violence and the history of inequality from the Stone Age to the twenty-first century. Princeton: Princeton University Press.

Scheidel, Walter and Friesen, Steven J. 2009. "The size of the economy and the distribution of income in the Roman empire." Journal of Roman Studies 99: 61-91.

Slack, Paul. 2004. "Measuring the national wealth in seventeenth-century England." Economic History Review 57: 607-635.

Spurr, M. Stephen. 1986. Arable cultivation in Roman Italy c.200 B.C. - c.A.D. 100. London: Society for the Promotion of Roman Studies.

Stephan, Robert P. 2013. "House size and economic growth: Regional trajectories in the Roman world." $\mathrm{PhD}$ dissertation Stanford University.

Temin, Peter. 2013. The Roman market economy. Princeton: Princeton University Press.

Von Freyberg, Hans-Ulrich. 1989. Kapitalverkehr und Handel im römischen Kaiserreich (27 v. Chr. - 235 n. Chr.). Freiburg im Breisgau: Rudolf Haufe Verlag.

Wilson, Andrew. 2011. "City sizes and urbanization in the Roman empire." In Bowman, Alan and Wilson, Andrew, eds. Settlement, urbanization, and population, 161-195. Oxford: Oxford University Press. 